\title{
Involvement of endothelial nitric oxide synthase pathway in IGF-1 protects endothelial progenitor cells against injury from oxidized LDLs
}

\author{
JING-WEN HAO ${ }^{1}$, GUO-FENG LIU $^{2}$, LI-ZHI XIAO ${ }^{1}$ and YONG-GANG WU ${ }^{1}$ \\ ${ }^{1}$ Positron Emission Tomography-Computed Tomography Center and ${ }^{2}$ Department of Nuclear Medicine, \\ The Second Xiangya Hospital, Central South University, \\ Changsha, Hunan 410011, P.R. China
}

Received February 5, 2018; Accepted October 8, 2018

DOI: $10.3892 / \mathrm{mmr} .2018 .9633$

\begin{abstract}
A high level of oxidized low-density lipoproteins (oxLDLs) is an independent risk factor for cardiovascular disease. The aim of the present study was to investigate whether insulin-like growth factor-1 (IGF-1) protected endothelial progenitor cells (EPCs) from injury caused by ox-LDLs, and whether the endothelial nitric oxide synthase (eNOS)/nitric oxide (NO) pathway was involved in this process. EPCs were isolated from human peripheral blood and characterized. In order to evaluate the effect of IGF-1 on EPCs, cells were incubated with ox-LDLs $(100 \mathrm{mg} / \mathrm{ml})$ for $24 \mathrm{~h}$ to induce a model of EPC dysfunction in vitro, which demonstrated a decrease in the number of EPCs, concomitant with increased apoptosis and decreased proliferation rates. IGF-1 dose-dependently increased the number of EPCs. Concurrently, IGF-1 decreased the levels of apoptosis of EPCs and improved EPCs proliferation following ox-LDLs challenge. In addition, IGF-1 significantly increased NO levels in ox-LDLs-treated EPCs, accompanied by an upregulation in eNOS expression. The protective effects of IGF-1 on EPCs and NO production were abolished by L-NAME, a specific eNOS inhibitor. These results suggested that IGF-1 protects EPCs from dysfunction induced by oxLDLs through a mechanism involving the eNOS/NO pathway.
\end{abstract}

\section{Introduction}

Cardiovascular complications resulting from atherosclerosis are the leading causes of morbidity and mortality in patients

Correspondence to: Dr Yong-Gang Wu, Positron Emission Tomography-Computed Tomography Center, The Second Xiangya Hospital, Central South University, 139 Renmin Road, Changsha, Hunan 410011, P.R. China

E-mail: wuyonggang@csu.edu.cn

Key words: endothelial progenitor cells, oxidized low density lipoprotein, nitric oxide, endothelial nitric oxide synthase with coronary heart disease (CHD) (1). Endothelial dysfunction is the first step in the initiation of atherosclerosis and is caused by endothelial injury and inflammation (2). The injured endothelial monolayer may be regenerated by circulating bone marrow-derived endothelial progenitor cells (EPC), which accelerate re-endothelialization and limit the progression of the atherosclerotic lesions (3). EPCs are precursor cells with high proliferation potential and capacity to differentiate into endothelial cells (3). EPCs also participate in physiological and pathological neovascularization (3), making them attractive for cell therapy targeting the regeneration of ischemic tissues $(4,5)$. Importantly, the numbers of circulating EPCs are low in certain diseases, including coronary artery disease (CAD) and diabetes (6-8). An improved understanding of the mechanisms by which EPCs are regulated may provide novel insights into therapeutic neovascularization, but the exact mechanism leading to EPC deficiency remains unknown.

A high level of circulating oxidized low-density lipoproteins (oxLDLs) is an independent predictor for future cardiac events (9-11). In addition, it has been demonstrated that oxLDLs may be one of the factors affecting the growth and bioactivity of EPCs. Indeed, Wang et al (12) indicated that oxLDLs decreased the numbers and activity of EPCs. Wu et al (13) suggested that oxLDLs regulated the number and function of EPCs through the p38 mitogen-activated protein kinase (p38 MAPK) pathway. Tie et al (14) revealed that oxLDLs disrupt the phosphoinositide 3-kinase/protein kinase B (PI3K/Akt) pathway in EPCs, leading to apoptosis. Lin et al (15) suggested that the effects of oxLDLs on EPCs were dose-dependent. Nevertheless, the underlying mechanism of the action remains largely unknown.

Insulin-like growth factor-1 (IGF-1) and the IGF-1 receptor affect the differentiation and apoptosis of various cells $(16,17)$. IGF-1 levels decrease during aging and are decreased in patients with CVD $(18,19)$. A low level of IGF-1 has been identified as an independent risk factor for CVD $(20,21)$. IGF-1 not only participates in protecting the endothelium but also affects the number and function of stem cells. Indeed, Urbanek et al (22) identified that IGF-1 improves the proliferation of cardiac stem cells, resulting in improved regeneration following heart infarction. Treatment of mice with IGF-1 
increases the number and function of EPCs (23). Agonists of the IGF-1 receptor improve EPC function (24). Furthermore, EPCs treated with IGF-1 exhibit increased expression and activity of the endothelial nitric oxide synthase (eNOS) (23).

Considering these data, it was hypothesized that IGF-1 may protect EPCs from induction of ox-LDLs, and that the eNOS axis is involved in this effect. Therefore, the present study aimed to investigate whether IGF-1 protects EPCs from injury caused by ox-LDLs via the eNOS/NO pathway in vitro. The results may provide novel insights for the eventual use of EPCs to treat patients with CVD.

\section{Materials and methods}

Preparation and oxidation of LDLs. Ethical approval was obtained by the Medical Ethics Committee of The Second Xiangya Hospital (Changsha, China). Human LDLs $(d=1.019-1.063 \mathrm{~g} / \mathrm{ml})$ were isolated by sequential ultracentrifugation $\left(235,000 \mathrm{x} \mathrm{g}\right.$ at $4{ }^{\circ} \mathrm{C}$ for $\left.24 \mathrm{~h}\right)$ of plasma from 20 normolipidemic subjects (10 males and 10 females from January to July 2017) following overnight fasting, as described previously (25). Informed consent was obtained. The purity of the LDLs was assessed by agarose gel electrophoresis and the protein concentration was determined by the modified Lowry method (26). The LDL particles were dialyzed by semi-permeable membrane (3500D) for $24 \mathrm{~h}$ with $0.01 \mathrm{M}$ PBS (pH 7.4) at $4^{\circ} \mathrm{C}$ to remove EDTA, then oxidized by exposure to $\mathrm{CuSO}_{4}$ $\left(10 \mathrm{mM} \mathrm{CuSO}_{4}, 24 \mathrm{~h}\right.$ at $\left.37^{\circ} \mathrm{C}\right)(27)$. EDTA was added and the LDL particles were dialyzed by semi-permeable membrane (3500D) for $24 \mathrm{~h}$ with PBS to terminate the oxidization at $4^{\circ} \mathrm{C}$. Thiobarbituric acid-reactive substances and agarose gel electrophoretic mobility were determined. oxLDLs were sterilized by passing through a $0.22-\mu \mathrm{m}$ Millipore filter (SLGP033RB; Merck KGaA, Darmstadt, Germany).

Isolation and culture of EPCs. EPCs were cultured as described previously $(28,29)$. Briefly, $40 \mathrm{ml}$ peripheral blood from healthy volunteers [aged 18 to 33 years old $(21.0 \pm 4.5$ years)] who provided informed consent were subjected to density gradient centrifugation (671 x g for $20 \mathrm{~min}$ at room temperature) with Histopaque-1077 (10771; Sigma-Aldrich; Merck KGaA) to isolate peripheral blood mononuclear cells (PBMCs). Following

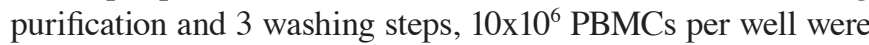
plated on fibronectin-coated 6-well plates. The cells were cultured in endothelial basal medium-2 (EBM-2; cat. no. CC3156; Clonetics; Lonza Group Ltd., Walkersville, MD, USA) with single EGM-2MV aliquots containing 5\% fetal bovine serum (Gibco; Thermo Fisher Scientific, Inc., Waltham, MA, USA), vascular endothelial growth factor (VEGF), fibroblast growth factor-2, epidermal growth factor, insulin-like growth factor and ascorbic acid. After 4 days, non-adherent cells were removed by washing with PBS. Fresh medium was added, and the culture was continued for 8 days. Non-adherent cells were removed again by washing with PBS and the adherent cells were considered as EPCs and harvested for subsequent experiments.

EPC characterization. To confirm the endothelial phenotype, the expression of endothelial protein markers was measured by flow cytometry (BD Biosciences, Franklin Lakes, NJ, USA). EPCs were detached with $1 \mathrm{mM}$ EDTA in PBS and incubated for 15 min with human fluorescein isothiocyanate (FITC)-conjugated kinase insert domain receptor (KDR; cat. no. FAB357F-025; R\&D Systems, Minneapolis, MN, USA), anti-vascular endothelium cadherin (cat. no. sc9989; Santa Cruz Biotechnology, Inc., Santa Cruz, CA, USA), phycoerythrin (PE)-conjugated cluster of differentiation 31 (CD31; cat. no. 553373; BD Biosciences), or rat anti-mouse FITC-conjugated cluster of differentiation 34 (CD34; DS-MB-03816; Raybiotech Life, Inc., Atlanta, GA, USA). For vascular endothelial cadherin (VE-cadherin) analysis, cells were first incubated with mouse anti-human VE-cadherin (cat. no. 555661; BD Biosciences; 1:1,000) for $30 \mathrm{~min}$ at $4^{\circ} \mathrm{C}$. Following washing with PBS twice for $5 \mathrm{~min}$ each, cells were incubated with FITC-conjugated goat anti-mouse secondary antibody (1:200) for $30 \mathrm{~min}$ at $4^{\circ} \mathrm{C}$ (cat. no. F9384: Sigma-Aldrich; Merck KGaA). Mouse IgG1 isotype control antibody (cat. no. 555121; BD Biosciences; 1:1,000) served as controls. Following incubation, the cells were fixed with $1 \%$ paraformaldehyde for $15 \mathrm{~min}$ at $4^{\circ} \mathrm{C}$ and quantitative analysis was performed on a FACScan flow cytometer (BD Biosciences) and analyzed with CellQuest software (version 5.1; BD Biosciences) with 20,000 cells/sample.

Treatment of EPCs. EPCs were treated without or with $100 \mathrm{mg} / \mathrm{ml}$ oxLDLs for $24 \mathrm{~h}$. EPCs in the IGF-1 group were pretreated with 0.1 or $0.5 \mu \mathrm{g} / \mathrm{ml} \mathrm{IGF-1} \mathrm{for} 30 \mathrm{~min}$ prior to exposure to oxLDLs, as described previously $(30,31)$. An additional group of cells was also pretreated with $100 \mu \mathrm{M}$ nomega-nitro-L-arginine methyl ester (L-NAME), an inhibitor of eNOS, for $60 \mathrm{~min}$ and then with $0.5 \mu \mathrm{g} / \mathrm{ml} \mathrm{IGF-1} \mathrm{for} 30 \mathrm{~min}$ prior to exposure to oxLDLs.

Apoptosis assay. Apoptosis was analyzed using an Annexin V/propidium iodide kit (556547; BD Biosciences). Briefly, $100 \mu \mathrm{l} 1 \times 10^{6} / \mathrm{ml}$ cells were incubated with $5 \mu \mathrm{l}$ Annexin V-FITC and $5 \mu \mathrm{l}$ propidium iodide (PI) for $15 \mathrm{~min}$ at room temperature. Following washing, the cells were diluted in $400 \mu \mathrm{l}$ Annexin V-binding buffer and immediately detected using a flow cytometer.

Proliferation assay. Mitogenic activity was measured using a colorimetric MTS assay (Cell-Titer 96 ${ }^{\circledR}$ AQueous Non-radioactive Cell Proliferation assay; cat. no. G1111; Promega Corporation, Madison, WI, USA). EPCs were harvested and seeded on a 96 -well plate $\left(1 \times 10^{4}\right.$ cells per well $)$ in $0.1 \mathrm{ml}$ EBM-2 medium supplemented with $0.5 \%$ bovine serum albumin (BSA; Gibco; Thermo Fisher Scientific, Inc.) in the presence of human recombinant vascular endothelial growth factor (100 ng/ml; cat. no. 293-VE-010; R\&D Systems). After $24 \mathrm{~h}$ the MTS/phenazine methosulfate solution was added to each well for $3 \mathrm{~h}$ and the absorbance at $570 \mathrm{~nm}$ was measured using an ELISA plate reader (S5 Versa Analyzer, Cellular Technology Ltd., Cleveland, OH, USA).

Immunofluorescence. Cells were suspended in $20 \mu \mathrm{l}$ PBS and incubated with $10 \mu \mathrm{g} / \mathrm{ml}$ 1,19-dioctadecyl-3,3,3939-tetramethylindocar-bocyanine perchlorate (Dil)-acetylated LDLs (ac-LDL) for $4 \mathrm{~h}$ at $37^{\circ} \mathrm{C}$. Following washing with PBS, the cells were fixed with $2 \%$ paraformaldehyde for $10 \mathrm{~min}$ at room temperature and incubated with FITC-Ulex europaeus 

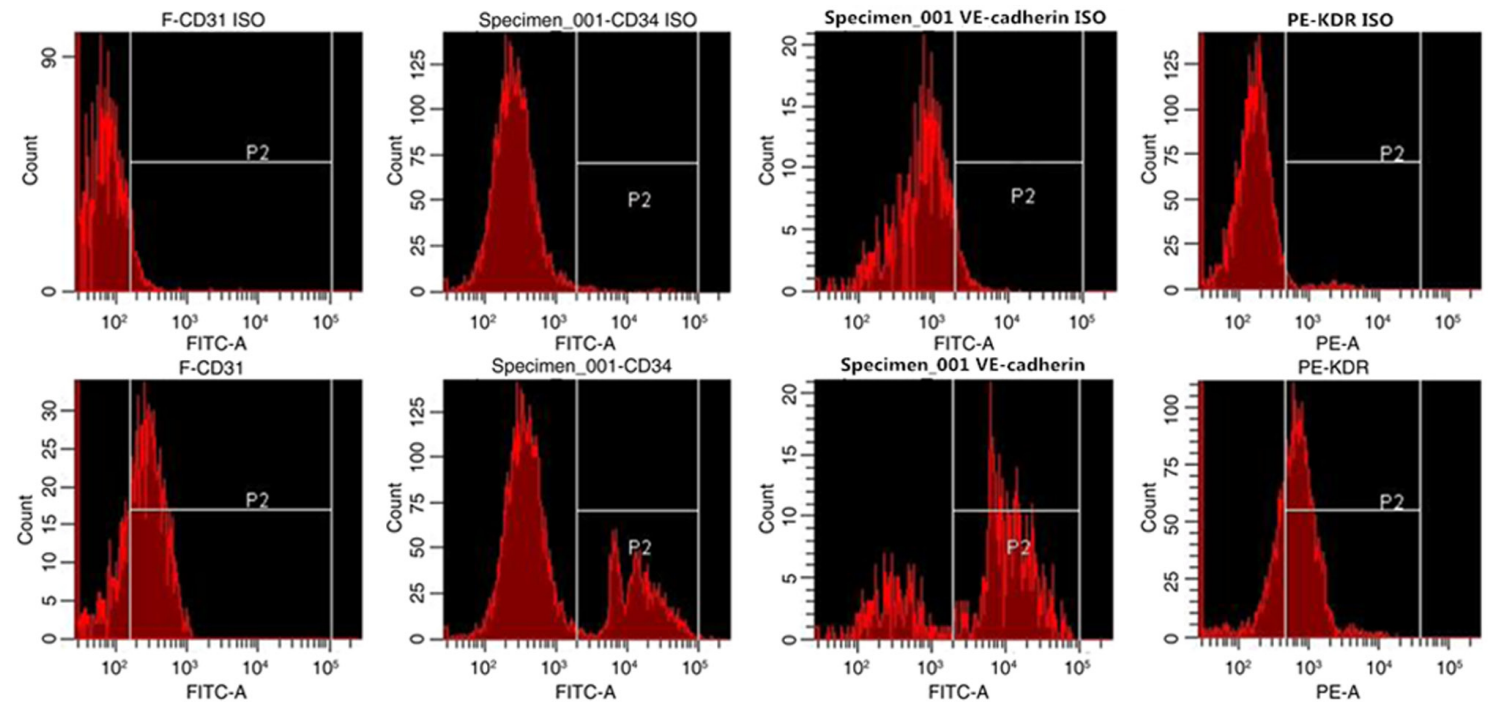

Figure 1. Identification of the EPCs using flow cytometry. The isolated EPCs were positive for CD31, CD34, VE-cadherin and KDR. EPCs, endothelial progenitor cells; $\mathrm{CD}$, cluster of differentiation; KDR, kinase insert domain receptor; FITC, fluorescein isothiocyanate; PE, phycoerythrin.

agglutinin 1 (UEA-1; $50 \mu \mathrm{g} / \mathrm{ml}$ ) for $1 \mathrm{~h}$ at $4^{\circ} \mathrm{C}$. The fluorescence signals were observed using an inverted fluorescence microscope (magnification, x200; Nikon Corporation, Tokyo, Japan).

Measurement of nitric oxide (NO) level. NO is an unstable product. Following metabolism, it transforms to nitrate and nitrite rapidly. In addition, it is difficult to measure NO directly. In the present study, $\mathrm{NO}$ production in EPCs were measured by a colorimetric assay kit (cat. no. A012; Nanjing Jiancheng Bioengineering Institute, Nanjing, China) using a nitrate reductase method according to the manufacturer's protocol. Absorbance was measured at $550 \mathrm{~nm}$ by a spectrophotometer. The NO concentration was expressed as $\mu \mathrm{mol} / \mathrm{l}$.

Western blot analysis. EPCs were washed and incubated in $75 \mu 1$ lysis buffer at $4^{\circ} \mathrm{C}$ for $40 \mathrm{~min}$, as described previously (32). The nuclear and cytosolic fractions were separated by a commercially available kit (NE-PRE Nuclear and Cytoplasmic Extraction Reagents) according to the protocol of the manufacturer (cat. no. 78833; Pierce Chemical Co., Dallas, TX, USA), as described previously (33). Proteins (30-50 $\mu \mathrm{g} /$ lane) measured by a bicinchoninc acid Protein Assay kit (Beyotime Institute of Biotechnology, Nanjing, China) were loaded on 10\% SDS-PAGE gels and blotted on polyvinylidene difluoride (PVDF) membranes. Then, PVDF membranes were incubated with $1 \%$ BSA at room temperature for $1 \mathrm{~h}$. Western blot analysis was then performed using antibodies against eNOS (1:500; mouse monoclonal anti-eNOS antibody; cat. no. 612706; BD Biosciences) at $4^{\circ} \mathrm{C}$ overnight. Following washing with TBST ( $0.1 \%$ Tween-20) for 3 times ( 5 min each), the PVDF membranes were incubated with a horseradish peroxidase-conjugated donkey anti-mouse secondary antibody (cat. no. SA00001-8; ProteinTech Group, Inc., Chicago, IL, USA; $1: 10,000$ ) for $1 \mathrm{~h}$ at room temperature. Finally, following washing with TBST, the autoradiographs were scanned and semi-quantitatively analyzed to calculate the protein ratio.

Statistical analysis. SPSS 22.0 statistical software (IBM Corp., Armonk, NY, USA) was used for data analysis. All data are

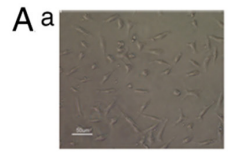

B

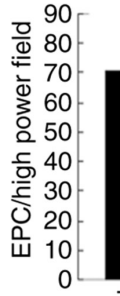

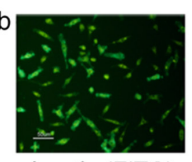

Lectin (FITC)

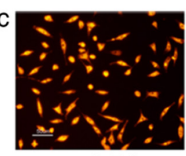

ac-LDL

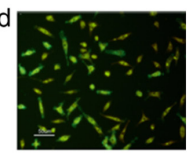

acLDL+Lectin
Number

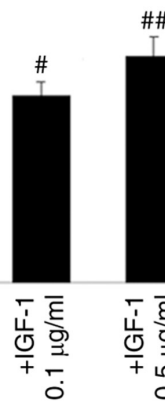

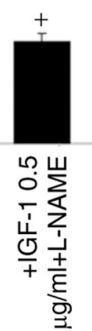

Figure 2. Identification and the number of EPCs. (A-a) Identification of the EPCs by immunofluorescence. Adherent cells were observed by optical microscopy. (A-b) FITC-lectin binding of EPCs. (A-c) 1,19-dioctadecyl-3,3,3 939-tetramethylindocar-bocyanine perchlorate (Dil)-labeled ac-LDLs uptake. (A-d) Double-positive cells were identified as differentiating EPCs. (B) Effect of IGF-1 on the numbers of EPCs following oxLDLs treatment. Treatment with $100 \mu \mathrm{g} / \mathrm{ml}$ oxLDL induced a decrease in EPC numbers. Pretreatment of EPCs with IGF-1 inhibited the decrease induced by oxLDLs. L-NAME inhibited these effects. Data are presented as mean \pm standard deviation. $(\mathrm{n}=6){ }^{*} \mathrm{P}<0.05$ vs. control; ${ }^{~} \mathrm{P}<0.05$ vs. oxLDL $(100 \mu \mathrm{g} / \mathrm{ml}) ;{ }^{\# \#} \mathrm{P}<0.05$ vs. $+\mathrm{IGF}-1(0.1 \mu \mathrm{g} / \mathrm{ml})$ group; ${ }^{+} \mathrm{P}<0.05$ vs. $+\mathrm{IGF}-1(0.5 \mu \mathrm{g} / \mathrm{ml})$ group. EPCs, endothelial progenitor cells; Dil, ac-LDLs, acetylated low-density lipoproteins; FITC, fluorescein isothiocyanate; IGF-1, insulin-like growth factor-1; oxLDLs, oxidized low density lipoproteins; L-NAME, nomega-nitro-L-arginine methyl ester.

presented as mean \pm standard deviation. Statistical analyses were performed using one-way analysis of variance followed by a Least Significant Difference test. $\mathrm{P}<0.05$ was considered to indicate a statistically significant difference.

\section{Results}

$L D L$ oxidation. The levels of thiobarbituric acid-reactive substances were $2.13 \pm 1.59$ and $24.4 \pm 8.31 \mathrm{nmol} / \mathrm{mg}$ protein 

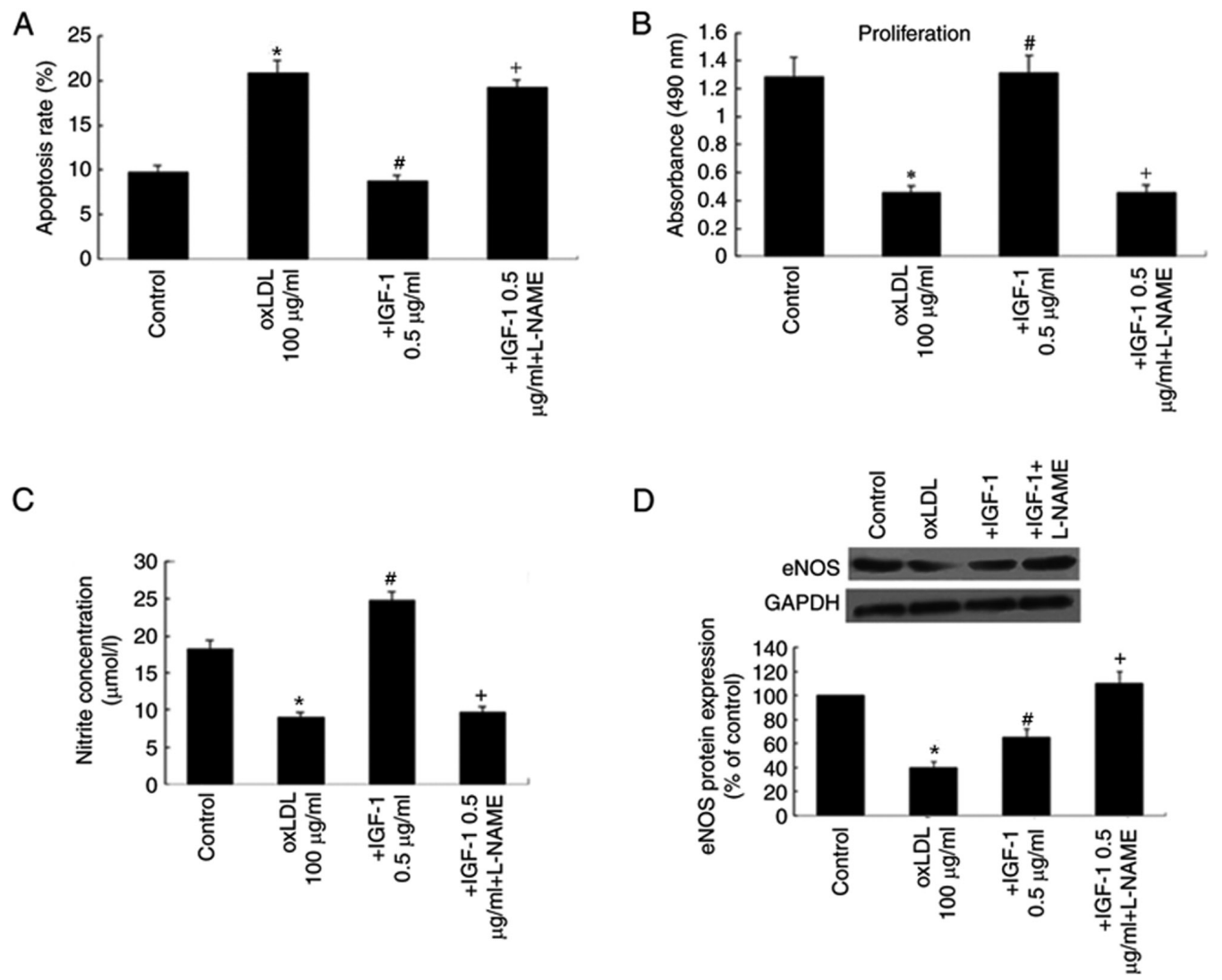

Figure 3. Effect of IGF-1 on EPC. (A) Effect of IGF-1 on the apoptosis levels of EPCs induced by oxLDLs. Treatment of EPCs with oxLDLs induced apoptosis. Pretreatment of EPC with $0.5 \mu \mathrm{g} / \mathrm{ml}$ IGF-1 inhibited oxLDLs-induced EPC apoptosis. This effect was significantly decreased by L-NAME. (B) Effect of IGF-1 on the proliferation of EPCs induced by oxLDLs. Treatment of EPCs with oxLDLs decreased proliferation. Pretreatment with $0.5 \mu \mathrm{g} / \mathrm{ml}$ IGF-1 enhanced oxLDLs-induced EPC proliferation. This effect was significantly decreased by L-NAME. Data are presented as mean \pm standard deviation. ( $\mathrm{n}=6$ ). ${ }^{*} \mathrm{P}<0.05 \mathrm{vs}$. control; ${ }^{\# P}<0.05$ vs. oxLDLs $(100 \mu \mathrm{g} / \mathrm{ml})$ group; ${ }^{+} \mathrm{P}<0.05 \mathrm{vs}$. +IGF-1 $(0.5 \mu \mathrm{g} / \mathrm{ml})$ group. (C) Effect of IGF-1 on NO generation of EPCs induced by oxLDLs. IGF-1 increases NO generation. Treatment of EPCs with oxLDLs decreased NO generation, which was restored by pretreatment with IGF-1. Treatment with L-NAME also inhibited NO generation. (D) Effect of IGF-1 on eNOS protein expression of EPCs. oxLDLs decreased eNOS protein expression, but pretreatment with IGF-1 dose-dependently inhibited this downregulation. Data are presented as mean \pm standard deviation; $n=3$. ${ }^{*} \mathrm{P}<0.05$ vs. control; ${ }^{*} \mathrm{P}<0.05$ vs. oxLDLs $(100 \mu \mathrm{g} / \mathrm{ml})$ group; ${ }^{+} \mathrm{P}<0.05 \mathrm{vs}$. +IGF-1 $(0.1 \mu \mathrm{g} / \mathrm{ml})$ group. EPCs, endothelial progenitor cells; IGF-1, insulin-like growth factor-1; oxLDLs, oxidized low density lipoproteins; L-NAME, nomega-nitro-L-arginine methyl ester; eNOS, endothelial nitric oxide synthase.

in native LDLs and oxLDLs, respectively. Compared with native LDLs, oxLDLs indicated a $1.4 \pm 0.4$ fold increase in electrophoretic mobility on agarose gels.

Isolation and identification of EPC. Flow cytometry was used to identify the endothelial phenotype of the EPCs. After 8 days of culture, the expression rates of KDR, VE-cadherin, $\mathrm{CD} 34$, and CD31 in the attached cells were 68.8 $77.5,73.9 \pm 6.3$, $25.4 \pm 9.1$ and $77.1 \pm 7.2 \%$, respectively (Fig. 1). After 8 days in culture, the attached cells took up Dil-acLDL and bound FITC-UEA-1 (Fig. 2A). Cells that were positive for these 2 factors simultaneously were considered EPCs. They constituted up to $90 \%$ of all attached cells. These results indicate that EPCs were successfully isolated from PBMCs.

$I G F-1$ increases the number of EPCs following oxLDL challenge. EPCs were characterized as adherent cells that were doubly-positive for lectin and Di-LDL. The toxic effects of oxLDLs were examined in EPCs; oxLDL significantly decreased the number of EPCs. IGF-1 (0.1 or $0.5 \mu \mathrm{g} / \mathrm{ml})$ significantly prevented the decrease of EPCs caused by oxLDLs; the effect of $0.5 \mu \mathrm{g} / \mathrm{ml}$ IGF-1 was more marked. When EPCs were incubated with L-NAME $(100 \mu \mathrm{M}), 0.5 \mu \mathrm{g} / \mathrm{ml} \mathrm{IGF-1} \mathrm{and}$
oxLDL for $24 \mathrm{~h}, \mathrm{~L}-\mathrm{NAMsE}$ significantly decreased the protective effect of IGF-1 against oxLDL (Fig. 2B). These results suggest that IGF-1 may protect EPCs against the toxic effects of oxLDL.

IGF-1 decreases apoptosis and increases proliferation of EPCs following oxLDL challenge. The increase in the number of EPCs following IGF-1 treatment may be attributed to a combination of factors, including inhibition of apoptosis and stimulation of proliferation. Therefore, the levels of apoptosis and proliferation of EPCs were examined following oxLDL challenge and in response to IGF-1. The results of the MTS assay demonstrated that treatment of EPCs with IGF-1 significantly prevented EPC apoptosis and improved EPC proliferation. These effects were significantly attenuated by L-NAME (Fig. 3A and B).

IGF-1 increases NO generation and upregulates eNOS protein. As the eNOS/NO axis may serve a role in the effects of IGF-1 on EPCs, the effects of IGF-1 on the eNOS protein were examined, and the effects of L-NAME, an eNOS inhibitor. $\mathrm{NO}$ generation was decreased by treatment with $100 \mathrm{mg} / \mathrm{ml}$ oxLDLs. This inhibitory effect of oxLDLs was prevented by 
the presence of $0.5 \mu \mathrm{g} / \mathrm{ml}$ IGF-1. Treatment with L-NAME significantly decreased NO generation compared with the $0.5 \mu \mathrm{g} / \mathrm{ml}$ IGF-1 group (Fig. 3C). To verify the hypothesis that IGF-1 protects EPCs against oxLDL through the eNOS pathway, eNOS protein expression was assessed by western blot analysis. Incubation of EPCs with $100 \mathrm{mg} / \mathrm{ml}$ oxLDL significantly suppressed eNOS protein expression. Pretreatment with IGF-1 caused a partial restoration of the downregulation of eNOS protein expression induced by oxLDL (Fig. 3D).

\section{Discussion}

In the present study, EPCs were cultured from circulating PBMCs. In agreement with previous studies (34-37), the isolated EPCs expressed a number of endothelial-specific cell surface markers including KDR, VE-cadherin, CD34, and CD31. They also exhibited several endothelial properties, including the uptake of Dil-acLDL and binding of FITC-UEA-1 $(38,39)$. IGF-1 alleviated the decrease in number of EPCs caused by oxLDLs, reversed the increased apoptosis and decreased proliferation rates, and increased the NO level. The protective effect of IGF-1 on EPCs and NO production were abolished by L-NAME, a specific inhibitor of eNOS. IGF-1 improved the decrease of eNOS induced by oxLDLs. These results suggest that IGF-1 protects EPCs from dysfunction induced by oxLDLs through a mechanism involving the eNOS/NO pathway.

Wu et al (13) suggested that oxLDL regulated the number and function of EPCs through the p38 MAPK pathway. Tie et al (14) indicated that oxLDL disrupted the PI3K/Akt pathway in EPCs, leading to apoptosis. Lin et al (15) demonstrated that the effects of oxLDLs on EPCs were dose-dependent. Several previous studies have indicated that IGF-1 protects endothelial cells from oxLDL: Higashi et al (30) revealed that IGF-1 alleviated oxLDL-induced oxidative stress and decreased cell senescence in human aortic endothelial cells, and $\mathrm{Wu}$ et al (40) demonstrated that IGF-1 counteracted the detrimental effects of oxLDL on the proliferation of EPCs.

Vascular lesions associated with the development of atherosclerosis are partly repaired by endogenous EPCs via NO-dependent mechanisms (41-43). NO is considered to be a significant regulator of neovascularization. Ma et al (44) revealed that oxLDLs decrease NO generation; as EPC survival depends on NO production, oxLDL-mediated decrease in NO production will lead to EPC death and decreased proliferation (44). The present study provided novel evidence indicating that IGF-1 increases proliferation and decreases apoptosis in EPCs induced by oxLDL, and that this effect is inhibited by L-NAME, a known inhibitor of eNOS. In agreement with these data, Bauersachs and Thum (40) also indicated that IGF-1 increases the bioavailability of NO in vivo, supporting the present study.

In addition, EPC mobilization is dependent upon eNOS; when eNOS is uncoupled, the mobilization and function of EPCs are impaired (45). eNOS is also necessary for EPC mobilization from the bone marrow (41). The results from the present study suggested that IGF-1 pretreatment dose-dependently reversed the decrease in eNOS expression caused by oxLDLs in EPCs. This suggests that the protective effect of IGF-1 against oxLDLs is mediated, at least in part, through the eNOS pathway. In agreement with this conclusion, Thum et al (23) demonstrated that treatment of EPCs with IGF-1 induced the expression and phosphorylation (ser1177) of eNOS (23). In cultured endothelial cells, IGF-1 increased NO production by eNOS through Akt-dependent pathways (46). We hypothesize that IGF-1 activates the IGF-1 receptor in EPCs. The IGF-1 receptor interacts with a tyrosine kinase membrane receptor that activates the PI3K/Akt signaling pathway $(47,48)$, facilitating eNOS expression and activity (49) and leading to the production of NO. Nevertheless, this hypothetic mechanism requires additional study for confirmation.

The data from the present study suggested a novel property of IGF-1, namely an increase in EPC numbers associated with increased proliferation and with decreased oxLDL-induced apoptosis. Although the proportional contributions of angiogenesis and vasculogenesis to neovascularization of adult tissue remain to be determined, it is well established that EPCs participate in repair following ischemic injury $(5,7,38,42,50-53)$. Therefore, increasing the number of circulating EPCs has been demonstrated to improve neovascularization of ischemic hind limbs $(39,52)$, accelerate blood flow in diabetic mice (53) and improve cardiac function (51). At present, treatment of mice with IGF-1 has been indicated to increase the number of EPCs (54). IGF-1 normalization improves cardiovascular outcomes in patients with growth hormone deficiency and low IGF-1 levels (55). Therefore, augmentation of circulating EPC numbers by IGF-1 may contribute significantly to the stimulation of neovascularization following tissue ischemia. This may eventually be a novel therapeutic strategy in patients with CAD.

Data from the present study and from Thum et al (23) demonstrated that IGF-1 increased the expression of eNOS in circulating EPCs and exerted a protective effect on EPCs. The differences between the present study and the study by Thum et al were as follows: Firstly, in the present study, the EPCs were isolated from peripheral blood of healthy young volunteers. However, circulating EPCs from young volunteers $(27.5 \pm 0.9$ years $)$ and elderly subjects $(74.1 \pm 0.9$ years $)$ were analyzed in the study by Thum et al (23); secondly, flow cytometry was used to identify the endothelial phenotype of the EPCs in the present study. After 8 days of culture, the expression rates of KDR, VE-cadherin, CD34, and CD31 in the attached cells were $68.8 \pm 7.5,73.9 \pm 6.3,25.4 \pm 9.1$ and $77.1 \pm 7.2 \%$, respectively. Conversely, Thum et al (23) classified CD133+/VEGFR+ cells as EPCs; thirdly, the present study indicated that IGF-1 dose-dependently increased the number of ox-LDLs injured EPCs. However, Thum et al (23) demonstrated that treatment of EPCs from elderly individuals with IGF-1 improved function and attenuated cellular senescence; finally, in the present study, IGF-1 was demonstrated to decrease apoptosis of EPCs and improve EPCs proliferation following ox-LDL challenge, potentially via the eNOS pathway, whereas Thum et al (23) indicated that IGF-1 increased eNOS expression, phosphorylation and activity in EPCs in a PI3K/Akt dependent manner.

The present study is not without limitations. The different methods of preparation of oxLDLs have been demonstrated to potentially yield different results (56) and only one method was used in the present study; nevertheless, the $\mathrm{CuSO}_{4}$ method has been revealed to produce oxLDLs that mimics those 
identified in advanced plaques (56). In addition, the different effectors and factors involved in NO production and eNOS regulation were not assessed. Additional studies are required to address this issue; future studies will involve establishing a hyperlipidemic rat model and treatment with IGF-1 or L-NAME. The number of circulating EPCs, EPCs function and the eNOS/NO axis will then be measured to support the data of the present study.

In conclusion, IGF-1 increases the number of oxLDLsinjured EPCs, potentially via the eNOS pathway. Increases in EPC numbers may be beneficial for endothelial regeneration and neovascularization, and for the inhibition of the development of atherosclerosis. The results suggest that IGF-1 and the eNOS pathway may be a therapeutic target for improving the prognosis of CHD.

\section{Acknowledgements}

Not applicable.

\section{Funding}

The present study was supported by the Project of China Hunan Health and Family Planning Commission (grant no. B20180147) and the Foundation of China Hunan Provincial Science and Technology Department (grant no. 2017SK50115).

\section{Availability of data and materials}

All data generated or analyzed during this study are included in this published article.

\section{Authors' contributions}

YGW conceived the study and designed the experiments. JWH, GFL and LZX performed the experiments. YGW and JWH analyzed the data and drafted the manuscript. All authors reviewed and approved submission of the manuscript.

\section{Ethical approval and consent to participate}

Ethical approval was awarded by the Medical Ethics Committee of The Second Xiangya Hospital (approval no., S042). Informed consent was gained from all participants.

\section{Patient consent for publication}

All volunteers approved publication of the manuscript.

\section{Competing interests}

All authors declare that they have no competing interests.

\section{References}

1. Lawton JS: Sex and gender differences in coronary artery disease. Semin Thorac Cardiovasc Surg 23: 126-130, 2011.

2. Matsuzawa Y and Lerman A: Endothelial dysfunction and coronary artery disease: Assessment, prognosis, and treatment. Coron Artery Dis 25: 713-724, 2014.
3. Du F, Zhou J, Gong R, Huang X, Pansuria M, Virtue A, Li X, Wang $\mathrm{H}$ and Yang XF: Endothelial progenitor cells in atherosclerosis. Front Biosci 17: 2327-2349, 2012.

4. Ii M: Bone marrow-derived endothelial progenitor cells: Isolation and characterization for myocardial repair. Methods Mol Biol 660: 9-27, 2010.

5. Bauer SM, Goldstein LJ, Bauer RJ, Chen H, Putt M and Velazquez OC: The bone marrow-derived endothelial progenitor cell response is impaired in delayed wound healing from ischemia. J Vasc Surg 43: 134-141, 2006

6. Vasa M, Fichtlscherer S, Aicher A, Adler K, Urbich C, Martin H, Zeiher AM and Dimmeler S: Number and migratory activity of circulating endothelial progenitor cells inversely correlate with risk factors for coronary artery disease. Circ Res 89: E1-E7, 2001.

7. Loomans CJ, de Koning EJ, Staal FJ, Rookmaaker MB, Verseyden C, de Boer HC, Verhaar MC, Braam B, Rabelink TJ and van Zonneveld AJ: Endothelial progenitor cell dysfunction: A novel concept in the pathogenesis of vascular complications of type 1 diabetes. Diabetes 53: 195-199, 2004.

8. Tepper OM, Galiano RD, Capla JM, Kalka C, Gagne PJ, Jacobowitz GR, Levine JP and Gurtner GC: Human endothelial progenitor cells from type II diabetics exhibit impaired proliferation, adhesion, and incorporation into vascular structures. Circulation 106: 2781-2786, 2002.

9. Shimada K, Mokuno H, Matsunaga E, Miyazaki T, Sumiyoshi K, Miyauchi K and Daida H: Circulating oxidized low-density lipoprotein is an independent predictor for cardiac event in patients with coronary artery disease. Atherosclerosis 174: 343-347, 2004.

10. Shimada K, Mokuno H, Matsunaga E, Miyazaki T, Sumiyoshi K, Kume A, Miyauchi K and Daida H: Predictive value of circulating oxidized LDL for cardiac events in type 2 diabetic patients with coronary artery disease. Diabetes Care 27: 843-844, 2004.

11. Gao S and Liu J: Association between circulating oxidized low-density lipoprotein and atherosclerotic cardiovascular disease. Chronic Dis Transl Med 3: 89-94, 2017.

12. Wang X, Chen J, Tao Q, Zhu J and Shang Y: Effects of ox-LDL on number and activity of circulating endothelial progenitor cells. Drug Chem Toxicol 27: 243-255, 2004.

13. Wu Y, Wang Q, Cheng L, Wang J and Lu G: Effect of oxidized low-density lipoprotein on survival and function of endothelial progenitor cell mediated by p38 signal pathway. J Cardiovasc Pharmacol 53: 151-156, 2009.

14. Tie G, Yan J, Yang Y, Park BD, Messina JA, Raffai RL, Nowicki PT and Messina LM: Oxidized low-density lipoprotein induces apoptosis in endothelial progenitor cells by inactivating the phosphoinositide 3-kinase/Akt pathway. J Vasc Res 47: 519-530, 2010.

15. Lin FY, Tsao NW, Shih CM, Lin YW, Yeh JS, Chen JW, Nakagami H, Morishita R, Sawamura T and Huang CY: The biphasic effects of oxidized-low density lipoprotein on the vasculogenic function of endothelial progenitor cells. PLoS One 10: e0123971, 2015.

16. Yu XY, Song YH, Geng YJ, Lin QX, Shan ZX, Lin SG and $\mathrm{Li}$ Y: Glucose induces apoptosis of cardiomyocytes via microRNA-1 and IGF-1. Biochem Biophys Res Commun 376: 548-552, 2008.

17. Vanamala J, Reddivari L, Radhakrishnan S and Tarver C: Resveratrol suppresses IGF-1 induced human colon cancer cell proliferation and elevates apoptosis via suppression of IGF-1R/Wnt and activation of p53 signaling pathways. BMC Cancer 10: 238, 2010.

18. Yousefzadeh G, Masoomi M,Emadzadeh A, Shahesmaeili A and Sheikhvatan M: The association of insulin-like growth factor-1 with severity of coronary artery disease. J Cardiovasc Med 14: 416-420, 2013.

19. AkturkIF, Yalcin AA,BiyikI,CaglarNT,Isiksacan N,Sarikamis C, Uzun F, Celik O and Caglar IM: The role of insulin-like growth factor- 1 in development of coronary no-reflow and severity of coronary artery disease in patients with acute myocardial infarction. Postepy Kardiol Interwencyjnej 10: 12-17, 2014.

20. Andreassen M, Raymond I, Kistorp C, Hildebrandt P, Faber J and Kristensen LØ: IGF1 as predictor of all cause mortality and cardiovascular disease in an elderly population. Eur J Endocrinol 160: 25-31, 2009.

21. Kaplan RC, Strickler HD, Rohan TE, Muzumdar R and Brown DL: Insulin-like growth factors and coronary heart disease. Cardiol Rev 13: 35-39, 2005. 
22. Urbanek K, Rota M, Cascapera S, Bearzi C, Nascimbene A De Angelis A, Hosoda T, Chimenti S, Baker M, Limana F, et al: Cardiac stem cells possess growth factor-receptor systems that after activation regenerate the infarcted myocardium, improving ventricular function and long-term survival. Circ Res 97: 663-673, 2005.

23. Thum T, Hoeber S, Froese S, Klink I, Stichtenoth DO, Galuppo P Jakob M, Tsikas D, Anker SD, Poole-Wilson PA, et al: Age-dependent impairment of endothelial progenitor cells is corrected by growth-hormone-mediated increase of insulin-like growth-factor-1. Circ Res 100: 434-443, 2007.

24. Fleissner F and Thum T: The IGF-1 receptor as a therapeutic target to improve endothelial progenitor cell function. Mol Med 14: 235-237, 2008

25. Senokuchi T, Matsumura T, Sakai M, Matsuo T, Yano M Kiritoshi S, Sonoda K, Kukidome D, Nishikawa T and Araki E: Extracellular signal-regulated kinase and p38 mitogen-activated protein kinase mediate macrophage proliferation induced by oxidized low-density lipoprotein. Atherosclerosis 176: 233-245, 2004.

26. Kannan Y, Sundaram K, Aluganti Narasimhulu C, Parthasarathy S and Wewers MD: Oxidatively modified low density lipoprotein (LDL) inhibits TLR2 and TLR4 cytokine responses in human monocytes but not in macrophages. J Biol Chem 287: 23479-23488, 2012

27. Tie G, Yan J, Messina JA, Raffai RL and Messina LM: Inhibition of p38 mitogen-activated protein kinase enhances the apoptosis induced by oxidized low-density lipoprotein in endothelial progenitor cells. J Vasc Res 52: 361-371, 2015.

28. Imanishi T, Hano T, Matsuo Y and Nishio I: Oxidized low-density lipoprotein inhibits vascular endothelial growth factor-induced endothelial progenitor cell differentiation. Clin Exp Pharmacol Physiol 30: 665-670, 2003

29. Imanishi T, Hano T and Nishio I: Angiotensin II potentiates vascular endothelial growth factor-induced proliferation and network formation of endothelial progenitor cells. Hypertens Res 27: 101-108, 2004.

30. Higashi Y,Pandey A, Goodwin B and Delafontaine P: Insulin-like growth factor-1 regulates glutathione peroxidase expression and activity in vascular endothelial cells: Implications for atheroprotective actions of insulin-like growth factor-1. Biochim Biophys Acta 1832: 391-399, 2013

31. Ji S, Ma Q, Luo X and Peng J: Protective effect of insulin-like growth factor-1 on vascular endothelial function in hypercholesterolemia and the underlying mechanism. Zhong Nan Da Xue Xue Bao Yi Xue Ban 38: 36-42, 2013 (In Chinese).

32. Dimmeler S, Aicher A, Vasa M, Mildner-Rihm C, Adler K, Tiemann M, Rütten H, Fichtlscherer S, Martin H and Zeiher AM: HMG-CoA reductase inhibitors (statins) increase endothelial progenitor cells via the PI 3-kinase/Akt pathway. J Clin Invest 108: 391-397, 2001.

33. Haendeler J, Hoffmann J, Diehl JF, Vasa M, Spyridopoulos I, Zeiher AM and Dimmeler S: Antioxidants inhibit nuclear export of telomerase reverse transcriptase and delay replicative senescence of endothelial cells. Circ Res 94: 768-775, 2004.

34. Peng J, Liu B, Ma QL and Luo XJ: Dysfunctional endothelial progenitor cells in cardiovascular diseases: Role of NADPH oxidase. J Cardiovasc Pharmacol 65: 80-87, 2015.

35. Luo S, Xia W, Chen C, Robinson EA and Tao J: Endothelial progenitor cells and hypertension: Current concepts and future implications. Clin Sci 130: 2029-2042, 2016.

36. Bianconi V, Sahebkar A, Kovanen P, Bagaglia F, Ricciuti B, Calabro P, Patti G and Pirro M: Endothelial and cardiac progenitor cells for cardiovascular repair: A controversial paradigm in cell therapy. Pharmacol Ther 181: 156-168, 2018.

37. Wils J, Favre J and Bellien J: Modulating putative endothelial progenitor cells for the treatment of endothelial dysfunction and cardiovascular complications in diabetes. Pharmacol Ther 170 98-115, 2017

38. Asahara T, Murohara T, Sullivan A, Silver M, van der Zee R, Li T, Witzenbichler B, Schatteman G and Isner JM: Isolation of putative progenitor endothelial cells for angiogenesis. Science 275 964-967, 1997.
39. Kalka C, Masuda H, Takahashi T, Kalka-Moll WM, Silver M, Kearney M, Li T, Isner JM and Asahara T: Transplantation of ex vivo expanded endothelial progenitor cells for therapeutic neovascularization. Proc Natl Acad Sci USA 97: 3422-3427, 2000.

40. Wu Y, Wang Q, Cheng L, Wang J, Sun X and Lu S: IGF-1 reduces the apoptosis of endothelial progenitor cells induced by oxidized low-density lipoprotein by the suppressing caspase-3 activity. Cell Res 18: S159, 2008

41. Aicher A, Heeschen C, Mildner-Rihm C, Urbich C, Ihling C, Technau-Ihling K, Zeiher AM and Dimmeler S: Essential role of endothelial nitric oxide synthase for mobilization of stem and progenitor cells. Nat Med 9: 1370-1376, 2003.

42. Friedrich EB, Walenta K, Scharlau J, Nickenig G and Werner N: CD $34 \%$ CD $133^{+} /$VEGFR-2 $2^{+}$endothelial progenitor cell subpopulation with potent vasoregenerative capacities. Circ Res 98: e20-e25, 2006

43. Bauersachs J and Thum T: Endothelial progenitor cell dysfunction: Mechanisms and therapeutic approaches. Eur J Clin Invest 37: 603-606, 2007

44. Ma FX, Zhou B, Chen Z, Ren Q, Lu SH, Sawamura T and Han ZC: Oxidized low density lipoprotein impairs endothelial progenitor cells by regulation of endothelial nitric oxide synthase. J Lipid Res 47: 1227-1237, 2006.

45. Thum T, Fraccarollo D, Schultheiss M, Froese S, Galuppo P, Widder JD, Tsikas D, Ertl G and Bauersachs J: Endothelial nitric oxide synthase uncoupling impairs endothelial progenitor cell mobilization and function in diabetes. Diabetes 56: 666-674, 2007.

46. Michell BJ, Griffiths JE, Mitchelhill KI, Rodriguez-Crespo I, Tiganis T, Bozinovski S, de Montellano PR, Kemp BE and Pearson RB: The Akt kinase signals directly to endothelial nitric oxide synthase. Curr Biol 9: 845-848, 1999.

47. Withers DJ, Burks DJ, Towery HH, Altamuro SL, Flint CL and White MF: Irs- 2 coordinates Igf- 1 receptor-mediated beta-cell development and peripheral insulin signalling. Nat Genet 23: 32-40, 1999.

48. Isenovic ER, Meng Y, Divald A, Milivojevic N and Sowers JR: Role of phosphatidylinositol 3-kinase/Akt pathway in angiotensin II and insulin-like growth factor-1 modulation of nitric oxide synthase in vascular smooth muscle cells. Endocrine 19: 287-292, 2002.

49. Dimmeler S, Fleming I, Fisslthaler B, Hermann C, Busse R and Zeiher AM: Activation of nitric oxide synthase in endothelial cells by Akt-dependent phosphorylation. Nature 399: 601-605, 1999.

50. Asahara T, Masuda H, Takahashi T, Kalka C, Pastore C, Silver M, Kearne M, Magner M and Isner JM: Bone marrow origin of endothelial progenitor cells responsible for postnatal vasculogenesis in physiological and pathological neovascularization. Circ Res 85: 221-228, 1999.

51. Kocher AA, Schuster MD, Szabolcs MJ, Takuma S, Burkhoff D, Wang J, Homma S, Edwards NM and Itescu S: Neovascularization of ischemic myocardium by human bone-marrow-derived angioblasts prevents cardiomyocyte apoptosis, reduces remodeling and improves cardiac function. Nat Med 7: 430-436, 2001.

52. Murohara T, Ikeda H, Duan J, Shintani S, Sasaki K, Eguchi H Onitsuka I, Matsui K and Imaizumi T: Transplanted cord blood-derived endothelial precursor cells augment postnatal neovascularization. J Clin Invest 105: 1527-1536, 2000.

53. Schatteman GC, Hanlon HD, Jiao C, Dodds SG and Christy BA: Blood-derived angioblasts accelerate blood-flow restoration in diabetic mice. J Clin Invest 106: 571-578, 2000.

54. Hou J, Peng X, Wang J, Zhang H, Xia J, Ge Q, Wang X, Chen X and $\mathrm{Wu} X$ : Mesenchymal stem cells promote endothelial progenitor cell proliferation by secreting insulinlike growth factor1. Mol Med Rep 16: 1502-1508, 2017.

55. Thum T, Fleissner F, Klink I, Tsikas D, Jakob M, Bauersachs J and Stichtenoth DO: Growth hormone treatment improves markers of systemic nitric oxide bioavailability via insulin-like growth factor-I. J Clin Endocrinol Metab 92: 4172-4179, 2007.

56. Higashi Y, Sukhanov S, Anwar A, Shai SY and Delafontaine P: IGF-1, oxidative stress and atheroprotection. Trends Endocrinol Metab 21: 245-254, 2010 